Kamil Mroczka

ORCID: 0000-0003-3809-3479

Uniwersytet Warszawski

Centrum Studiów Samorządu Terytorialnego i Rozwoju Lokalnego

\title{
Pozycja i rola wojewody w systemie decydowania publicznego w okresie II Rzeczypospolitej (w latach 1919-1928) w kontekście tworzenia struktur administracji terytorialnej
}

DOI: 10.19195/1643-0328.26.9

Słowa kluczowe: wojewoda, decydowanie publiczne, administracja rządowa, administracja terytorialna, II Rzeczpospolita

\section{Wprowadzenie}

Celem artykułu jest analiza zagadnienia umiejscowienia i roli wojewody w systemie decydowania publicznego II RP w kontekście procesu tworzenia struktur administracyjnych. Jest to ważne zagadnienie, ponieważ model ustrojowy polskiej administracji ogólnej w terenie po pierwszej wojnie światowej kształtował się imponująco szybko. Jak zauważa Jacek Majchrowski, było to jednym „z fundamentalnych warunków rzeczywistego zaistnienia Państwa Polskiego"1. Autor przywołuje również słowa generała-gubernatora Hansa von Beselera, który stwierdził, że

stworzenie rządu mogącego sprostać wymaganiom nowoczesnej państwowości i opartego na szerokich podstawach demokratycznych jest sprawą dziesiątków lat. Nawet w Niemczech, mimo znanej karności i zdolności organizacyjnych narodu niemieckiego, trwał od początku zeszłego wieku [...] aż do roku 1872, w którym była wprowadzona reforma wyborcza. Niezależnie od tego należy sobie zdać jasno sprawę z okoliczności, że Polacy nie mają obecnie pierwiastków, na których państwowość taką można by oprzeć. Brak wam przede wszystkim niższych urzędników, którzy stanowią o sprawności machiny administracyjnej².

Jak pokazały wydarzenia z okresu dwudziestolecia międzywojennego, teza ta była nieuzasadniona, gdyż wiele rozwiązań wypracowanych w tym czasie było innowacyjnych,

${ }^{1}$ J. Majchrowski, Ewolucja funkcji wojewody jako przedstawiciela Rzadu, Warszawa 2011, s. 34.

2 Ibidem, s. 35. 
a część z nich jest nadal aktualna ${ }^{3}$. Twierdzenie to wysuwa się również na pierwszy plan w rozważaniach Huberta Izdebskiego i Michała Kuleszy, którzy podkreślają, że II RP przyjęła „austriacki model procedury administracyjnej i sądownictwa administracyjnego, pruski - co do zasady - model samorządu terytorialnego oraz rosyjskie wzory instytucji finansowych, łącznie z koncepcją Najwyższej Izby Kontroli”. Podkreślają jednak, że stworzony model „nie był zlepkiem przypadkowych zapożyczeń z różnych dawnych systemów. Był to - jako całość - system oryginalny, zapewniający należyte wywiązywanie się przez państwo z większości zadań, które powinno ono było wypełniać" 4 . Wacław Kumaniecki słusznie podkreślał, że „Polska tworzyła swoją administrację w tak niepomyślnych warunkach, że doprawdy chybaby było rzeczą bardzo trudną znaleźć drugi podobny przykład w dziejach. Nie mogła tego robić ani spokojnie ani systematycznie" 5 .

Szczegółowe rozważania zawarte w artykule będą odnosić się do istotnego elementu odradzającego się systemu administracyjnego uosobionego w urzędzie wojewody.

Nie wchodząc w skrupulatne rozważania definicyjne, na potrzeby niniejszego artykułu przyjęto, że decydowanie publiczne jest aktywnością decyzyjną tych podmiotów, które „poprzez swoje rozstrzygnięcia uczestniczą w programowaniu, organizowaniu i ukierunkowywaniu działań państwa, terytorialnych wspólnot regionalnych i lokalnych $\mathrm{w}$ państwie oraz w kształtowaniu relacji publicznych z podmiotami instytucjonalnymi funkcjonującymi w przestrzeni ponadpaństwowej i międzynarodowej”6.

W takim ujęciu decydowanie publiczne koncentruje się na zagadnieniach „związanych z koegzystencją władzy, prawa i polityki, dystrybucją dóbr oraz usług materialnych i niematerialnych, a także zarządzaniem zasobami publicznymi”" . Nie ulega wątpliwości, że wojewoda spełnia przedstawione kryteria.

Hipoteza przyjęta na potrzeby niniejszego artykułu brzmi następująco: wojewoda stanowił kluczowy element systemu administracyjnego odradzającej się państwowości polskiej i - w sposób bezpośredni oraz pośredni - wpływał na kluczowe procesy decyzyjne w sferze publicznej. Zakres kompetencji merytorycznych, organizacyjnych i politycznych lokował wojewodę wśród najważniejszych czynników państwowotwórczych i administracyjnych, jednak $\mathrm{z}$ uwagi na niepełne zespolenie rządowej administracji tere-

${ }^{3}$ Zob. szerzej bogatą literaturę poświęconą kształtowaniu się systemu administracji publicznej po pierwszej wojnie światowej: A. Bosiacki, Od naturalizmu do etatyzmu. Doktryny samorzadu terytorialnego Drugiej Rzeczypospolitej 1918-1939, Warszawa 2006; R. Chwedoruk, Polskie tradycje samorządowe. Samorząd terytorialny w polskiej myśli politycznej, „Społeczeństwo i Polityka” 2006, nr 1 (6); H. Izdebski, Samorząd terytorialny w II Rzeczypospolitej, [w:] Samorzad terytorialny. Zagadnienia prawne i administracyjne, red. A. Piekara, Z. Niewiadomski, Warszawa 1998; R. Szwed, Samorząd terytorialny w Polsce w latach 1918-1939. Wybór materiałów źródłowych, Częstochowa 2000; A. Bosiacki, U podstaw doktryny samorządu terytorialnego II RP. Naturalistyczna i państwowa teoria samorządu terytorialnego i jej geneza w europejskiej myśli prawnej, „Czasopismo Prawno-Historyczne" 2005, z. 2.

${ }^{4}$ H. Izdebski, M. Kulesza, Administracja publiczna. Zagadnienia ogólne, Warszawa 2000, s. 59.

5 W. Kumaniecki, Wzmocnienie państwa a administracja, „Gazeta Administracji i Policji Państwowej” 12.01.1924, s. 26 (2).

${ }^{6}$ G. Rydlewski, Wstęp, [w:] Decydowanie publiczne. Polska na tle innych państw członkowskich Unii Europejskiej, red. G. Rydlewski, Warszawa 2011, s. 10.

7 Ibidem, s. 10-11. 
nowej oraz niestabilność sceny politycznej funkcja ta nie była realizowana zgodnie z modelowymi założeniami projektodawców systemu administracji okresu międzywojnia.

\section{Początki organizowania się państwowości polskiej i systemu administracyjnego w latach 1919-1921}

Jak podkreślał Stanisław Kasznica, w pierwszej fazie kształtowania się aparatu państwa polskiego

zapanowała na razie wszechwładnie zasada specjalizacji. Każda władza naczelna usiłowała rozbudować własne organy terytorialne zupełnie samodzielnie, niezależnie od urzędów innych działów [...]. Od razu jednak okazały się ujemne następstwa takiej organizacji: brak wszelkiej koordynacji pomiędzy wszystkimi tymi urzędami, przewlekłość załatwiania każdej sprawy, która wymagała porozumienia paru urzędów, strata czasu publiczności, kosztowność takiego aparatu, przeciążenie organów gminnych, będących wykonawcami władz powiatowych, nadmierną ilością zleceń, najczęściej nie uzgodnionych ze sobą, sprzecznych nawet sobie itp. ${ }^{8}$

Konsekwencjami przyjętego - w pierwszym etapie kształtowania struktur państwa - modelu jednoinstancyjnej struktury administracji terenowej były: chaos kompetencyjny, opieszałość w załatwianiu spraw oraz podejmowanie błędnych decyzji wpływających negatywnie na funkcjonowanie państwa9. W odpowiedzi na zidentyfikowane problemy podjęto działania legislacyjne. W sierpniu 1919 roku uchwalono ustawę tymczasową o organizacji władz administracyjnych ${ }^{10}$. Regulacja ta miała rozpocząć proces tworzenia podwalin systemu administracyjnego, scalanego z różnych modeli państw zaborczych. Na mocy ustawy powołano do życia pięć województw ${ }^{11}$ i ustanowiono Warszawę jako stolicę.

Zgodnie $\mathrm{z}$ art. 2 ustawy na czele województwa stał wojewoda mianowany przez Naczelnika Państwa. Był

przedstawicielem Rządu centralnego, sprawującym z jego ramienia władzę państwową i odpowiedzialnym wobec niego za zarząd województwa; [...] odpowiedzialnym wykonawcą zleceń poszczególnych ministrów; zwierzchnikiem władz i urzędów, które mu podlegają (art. 3), tudzież służbowym przełożonym urzędników tychże władz i urzędników ${ }^{12}$.

W świetle przywołanej regulacji urząd wojewody miał dualistyczny charakter. Z jednej strony był przedstawicielem rządu na terenie województwa (funkcja stricte politycz-

8 S. Kasznica, Polskie prawo administracyjne. Pojęcia i instytucje zasadnicze, Poznań 1947, s. 55-56.

9 Zob. W. Kozyra, Urząd wojewódzki w Lublinie w latach 1919-1939, Lublin 1999, s. 26 n. Por. także przywołaną tam literaturę oraz materiały źródłowe.

10 Ustawa tymczasowa $\mathrm{z}$ dnia 2 sierpnia 1919 roku o organizacji władz administracyjnych II instancji, Dz.Pr.P.P. z 1919 r. Nr 65, poz. 395 (dalej: ustawa z 1919 r.).

11 Powołano województwa: warszawskie, łódzkie, kieleckie, lubelskie i białostockie. Zob. art. 1 ustawy z 1919 r.

12 Art. 3 ustawy z 1919 r. 
na), z drugiej zaś zwierzchnikiem wojewódzkiej administracji ogólnej (funkcja administracyjna $)^{13}$.

Do zakresu działania wojewodów zaliczono „wszelkie sprawy administracji państwowej z wyjątkiem spraw przekazanych administracji wojskowej, sądowej, skarbowej, szkolnej, kolejowej i pocztowo-telegraficznej oraz urzędów ziemskich". Przy wojewodzie utworzono istotny organ — radę wojewódzką — jako swoisty surogat przedstawicielstwa samorządu wojewódzkiego ${ }^{14}$. Zadaniem rady było wydawanie opinii w sprawach poddanych pod jej obrady przez wojewodę, a także podejmowanie uchwał w sprawach przekazanych jej przez ustawodawstwo zwykłe. Radzie przewodniczył wojewoda, co zdecydowanie wzmacniało jego pozycję prawną i faktyczną. Było to również przejawem podejścia do roli samorządu terytorialnego, który w świetle analizowanej koncepcji był podporządkowany administracji rządowej. W opinii Romana Hausnera instytucja rady wojewódzkiej dążyła

z jednej strony przez udział reprezentantów samorządu do zharmonizowania czynnika obywatelskiego w administracji państwowej, zaś z drugiej przez udział urzędników, reprezentujących także te dziedziny administracji, które wojewodzie nie podlegają, do zharmonizowania całej administracji państwowej na obszarze województwa ${ }^{15}$.

Omawiana ustawa miała charakter dość ogólny i regulowała podstawowe kwestie w zakresie nowo tworzonej struktury administracyjnej. Doprecyzowanie roli i pozycji wojewody następowało w drodze aktów wykonawczych Rady Ministrów. Pierwszy z nich wydano 13 listopada 1919 roku $^{16}$.

Powołane rozporządzenie zostało podzielone na kilka części, odnoszących się między innymi do stanowiska wojewody i jego stosunku służbowego, zakresu działania wojewody, działalności orzeczniczej, stosunku do urzędów podległych oraz organizacji urzędu wojewódzkiego. Warto $\mathrm{w}$ tym miejscu podkreślić, że władzą administracyjną był wojewoda i starosta, a nie województwo czy starostwo. Urzędy te bowiem nie miały „charakteru władzy”, a były ,jedynie technicznym aparatem administrowania dla starosty i wojewody"17.

Wojewoda na obszarze województwa był „przedstawicielem Rządu Centralnego" i dzierżył „Z jego ramienia władzę państwową". Z udziałem rady wojewódzkiej, urzędów i organów podległych wojewoda sprawował tak zwany zarząd województwa, za który był odpowiedzialny bezpośrednio przed rządem centralnym. Wojewodów mianował, przenosił i „uwalniał” Naczelnik Państwa. Powoływanie wojewodów przez najwyższe władze Rzeczypospolitej z całą pewnością wpływało na pozycję polityczną

13 W. Kozyra, op. cit., s. 26.

14 Ibidem. Zob. R. Hausner, Organizacja władz administracyjnych, „Gazeta Administracji i Policji Państwowej" 24.06.1922, s. 382 (2).

15 Ibidem.

16 Rozporządzenie wykonawcze Rady Ministrów do ustawy tymczasowej z dnia 2 sierpnia 1919 roku o organizacji władz administracyjnych drugiej instancji, Dz.U. z 1919 r. Nr 90, poz. 490 (dalej: rozporządzenie z 1919 r.).

17 J. Starościak, Administracyjny ustrój Polski, Warszawa 1947, s. 22. 
i faktyczną wojewodów w terenie. Od 1922 roku wojewodów mianował, przenosił i zwalniał ze stanowiska Prezydent, co jeszcze bardziej wzmocniło ich pozycję ${ }^{18}$. Można uznać, że był to typowy element w kształtowaniu modelu unitaryzmu scentralizowanego w systemie administracyjno-terytorialnym państwa. Model ten umożliwił budowę reżimu autorytarnego po 1926 roku. W piśmiennictwie słusznie podkreśla się, że w unitarnych systemach scentralizowanych zakres uprawnień władczych i decyzyjnych organów centralnych jest szczególnie duży, „uniemożliwiający w praktyce podejmowanie decyzji na szczeblu lokalnym lub regionalnym" ${ }^{19}$.

Wojewodowie pod względem personalnym podlegali Ministrowi Spraw Wewnętrznych, służbowo zaś poszczególnym ministrom działowym ${ }^{20}$. Do zakresu działania wojewodów należały „wszelkie sprawy administracji państwowej z wyjątkiem spraw przekazanych administracji sądowej, skarbowej, szkolnej, wojskowej, kolejowej i pocztowo-telegraficznej oraz spraw zastrzeżonych kompetencji Urzędów Ziemskich". W zakresie powierzonych zadań wojewoda był „odpowiedzialnym wykonawcą zleceń poszczególnych Ministrów tudzież organem zarządzającym, orzekającym, rozstrzygającym lub wnioskującym"21.

Wojewodom na mocy analizowanego aktu prawnego przyznano prawo do wydawania w zakresie swojej kompetencji rozporządzeń wykonawczych. Akty te mogły zawierać sankcje dla osób i podmiotów, które się do nich nie stosowały. Aby rozporządzenie nabrało mocy obowiązującej, musiało być ogłoszone w dzienniku wojewódzkim i podane do publicznej wiadomości. Dodatkowo wojewoda miał prawo wydawać zarządzenia.

Ważnym aspektem w działalności wojewodów były uprawnienia w zakresie zabezpieczenia „spokoju i bezpieczeństwa publicznego w powierzonym województwie”. Wojewoda decydował o użyciu oddziałów policji, a w sytuacjach nadzwyczajnych i wyjątkowych miał prawo wnioskować o pomoc wojska. Sprawował również „nadzór nad prasą, widowiskami, sprawami paszportowemi, sprawami obcych poddanych, ruchem ludności, jakoteż nad zgromadzeniami, stowarzyszeniami i związkami”22.

Jak wynika $\mathrm{z}$ treści regulacji prawnych, zakres działania wojewodów był szeroki. Można zaryzykować twierdzenie, że wojewoda uczestniczył w procesach kluczowych, zarówno dla obywateli, jak i innych interesariuszy. Zakres kompetencji wojewody w wybranych politykach publicznych prezentuje rycina nr 1 .

18 K. Wojtczak, Pozycja prawna wojewody, Warszawa 1986, s. 8.

19 J. Knopek, Europejskie systemy polityczne, Warszawa 2016, s. 107 n.

20 Zgodnie z art. 4 rozporządzenia: „W razie niemożności pełnienia przez Wojewodę obowiązków służbowych, zastępuje go w nich ten z pomiędzy pozostających na etacie Ministerstwa Spraw Wewnętrznych Naczelników Departamentu, któremu Wojewoda zastępstwo poruszy. Na zastępcę przechodzą w okresie zastępstwa wszelkie prawa i obowiązki Wojewody", zob. rozporządzenie z 1919 r.

21 Art. 5 rozporządzenia z $1919 \mathrm{r}$.

22 Art. 7 rozporządzenia z $1919 \mathrm{r}$. 


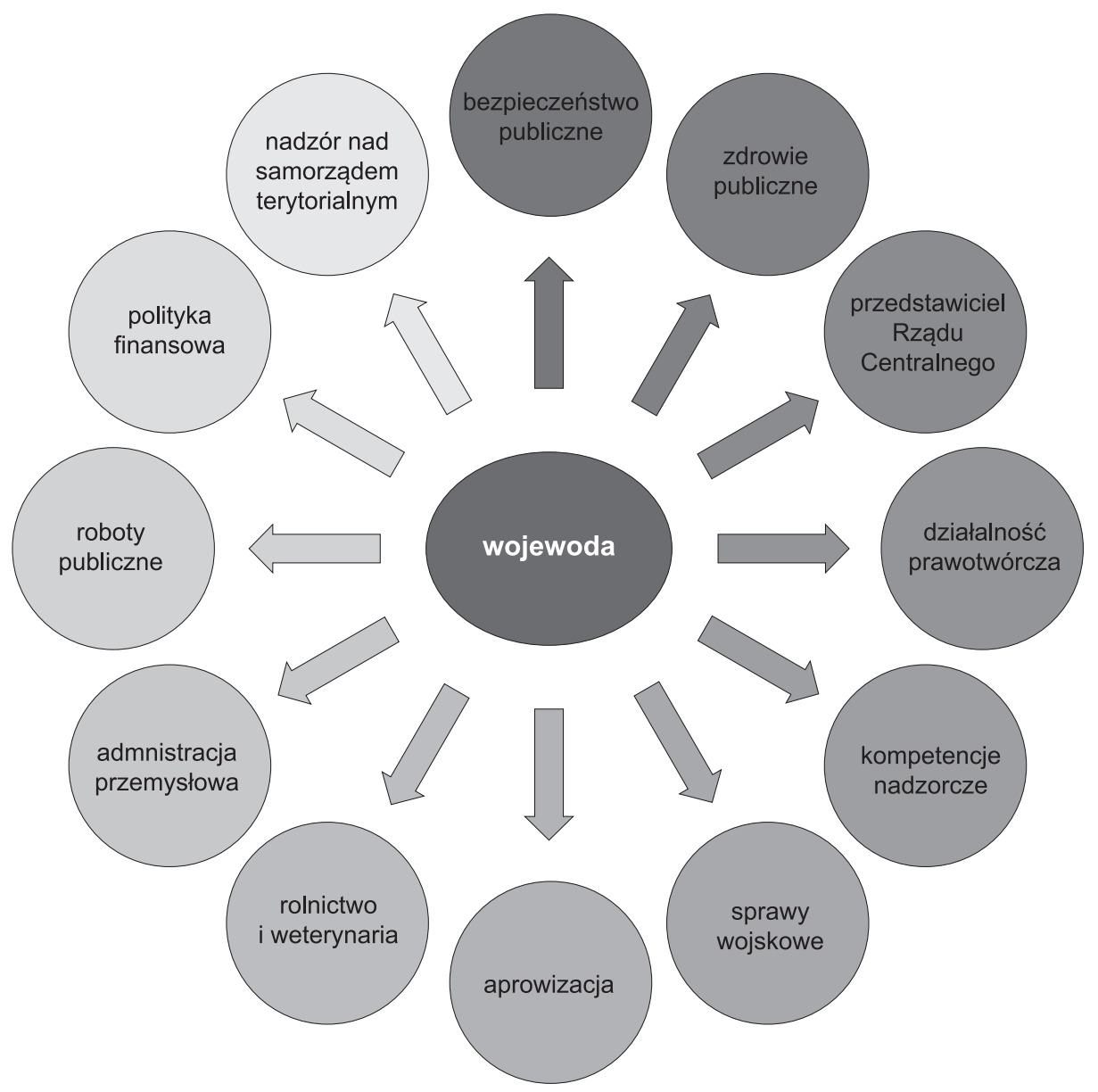

Rycina 1. Pola decydowania wojewody w okresie unifikacji systemu administracji publicznej II Rzeczypospolitej (1919-1928)

Źródło: opracowanie własne na podstawie rozporządzenia wykonawczego Rady Ministrów do ustawy tymczasowej z dnia 2 sierpnia 1919 r. o organizacji władz administracyjnych drugiej instancji, Dz.U. z 1919 r. Nr 90, poz. 490.

W kontekście prowadzonych rozważań warto omówić charakter relacji wojewodapodległe urzędy i ich kierownicy. Zgodnie z art. 21 rozporządzenia wojewodę ustanowiono zwierzchnikiem wszystkich (poza nielicznymi wyjątkami) istniejących na terenie województwa urzędów i organów, zarówno państwowych, jak i samorządowych. $\mathrm{Na}$ mocy tego uprawnienia wojewoda wykonywał tak zwany nadzór ogólny i czuwał nad legalizmem działania poszczególnych urzędów i organów. Dodatkowo wojewoda nadawał podległym mu urzędom i organom ,jednolity kierunek działania, dążący do zapewnienia pieczy państwowej wszystkim mieszkańcom powierzonego sobie obszaru i zmierzający do ogólnego rozwoju województwa"23.

23 Art. 21 rozporządzenia z 1919 r. 
W ramach tej aktywności decyzyjnej wojewoda zobowiązany był przynajmniej raz w roku zorganizować spotkanie wszystkich „Starostów, Naczelników Departamentów i Kierowników Oddziałów celem omówienia organizacji jakoteż działalności władz i urzędów Wojewodzie podległych". Uczestnicy zjazdu mogli przedstawić wojewodzie „wszystkie ujemne strony tak organizacji jak i działalności tych instytucji” oraz mieli „prawo czynić wnioski dążące do usunięcia braków”24.

W ramach omawianej kompetencji wojewoda „znosił lub zmieniał z urzędu wszystkie sprzeczne $\mathrm{z}$ obowiązującymi przepisami lub interesem publicznym rozporządzenia, zarządzenia, rozstrzygnięcia i orzeczenia podległych mu urzędów i organów, o ile przez to nie zostały naruszone prawa osób trzecich" ${ }^{25}$. Dzięki temu mógł znacznie wpływać na rzeczywistość społeczną, gospodarczą i przede wszystkim polityczną. Ważnym atrybutem władzy wojewody w zakresie polityki personalnej było prawo mianowania funkcjonariuszy podległych mu urzędów, możliwość wyznaczania miejsc wykonywania obowiązków oraz sprawowanie nad wszystkimi funkcjonariuszami podległych mu władz i urzędów władzy dyscyplinarnej ${ }^{26}$.

Jak wspomniano, przy wojewodach powołano radę wojewódzką, która pełniła funkcję opiniodawczą w zakresie spraw o charakterze społecznym oraz innych poddanych pod jej obrady przez wojewodę. Skierowanie sprawy pod obrady rady było suwerenną decyzją wojewody. Funkcję przewodniczącego rady pełnił wojewoda lub wyznaczony przez niego urzędnik. W skład rady wchodzili delegaci sejmików i rad miejskich wydzielonych oraz kierownicy poszczególnych działów administracji wojewódzkiej i przedstawiciele działów nienależących do tego zarządu.

Ustawodawca zalecił, aby wojewodowie zasięgali opinii rady

we wszystkich sprawach większego znaczenia dla Województwa tak pod względem gospodarczym, jak i kulturalnym, a w szczególności w sprawach aprowizacyjnych, budowy kolei, kanałów, portów, regulacji rzek, zmiany granic województwa i powiatów, ulg podatkowych spowodowanych klęskami żywiołowemi na znaczniejszej przestrzeni Województwa, budowy szpitali większych, zakładów humanitarnych itp. oraz we wszystkich sprawach ważniejszych, wchodzących w zakres działalności komunalnych ${ }^{27}$.

W przypadku sformułowania przez radę lub sekcję (jednostkę organizacyjną rady) „stanowczej uchwały" wojewoda zobowiązany był przekazać sprawę do ponownego rozpatrzenia lub zawiesić jej procedowanie, przy czym zawieszenie procesowania wiązało się z koniecznością przekazania sprawy do rozstrzygnięcia właściwemu ministrowi.

Co szczególnie istotne, wojewoda był „odpowiedzialny za wszystkie zarządzenia, wydane przez siebie na podstawie opinji lub uchwał Rady Wojewódzkiej względnie jej Sekcji”, zaś „okoliczność, że wydał je w myśl tych uchwał lub opinji”, nie zmniejszała jego odpowiedzialności ${ }^{28}$. Przepis ten wprowadzał niewątpliwie istotny mechanizm wpływający na procesy decyzyjne realizowane przez wojewodów. $Z$ jednej bowiem strony wojewodowie zobowiązani byli do szanowania i uwzględniania w procesie decyzyjnym stanowiska rady,

\footnotetext{
24 Art. 30 rozporządzenia z $1919 \mathrm{r}$.

${ }^{25}$ K. Wojtczak, op. cit., s. 8.

26 Zob. art. 24-30 rozporządzenia z 1919 r.

27 Art. 32 rozporządzenia z $1919 \mathrm{r}$.

28 Ibidem.
} 
z drugiej zaś odpowiedzialność za podejmowane decyzje była odpowiedzialnością indywidualną. Analizując wpływ tego rozwiązania na proces decydowania, należy zauważyć, że zachęcało ono do unikania kierowania spraw do rozpatrywania przez radę.

Instytucjonalną formą wsparcia wojewody $\mathrm{w}$ realizacji przypisanych prawem kompetencji był urząd wojewódzki, w którego skład wchodziły departamenty i oddziały jako ich jednostki organizacyjne.

Jak wykazano, jednym z kluczowych założeń ustrojowych systemu administracji odradzającej się Rzeczypospolitej Polskiej była kwestia zespolenia organów administracji państwowej. Postulat ten wdrażano stopniowo od 1920 roku $^{29} \mathrm{w}$ związku z utworzeniem województwa jako jednostki podziału terytorialnego. Województwo spełniało zasadnicze założenie zespolenia, gdyż na jego czele stał wojewoda, który miał wiele kompetencji związanych $\mathrm{z}$ administracją zarówno zespoloną, jak i niezespoloną.

Warto jednak podkreślić, że $\mathrm{w}$ omawianym okresie zespolenie przybierało jedną $\mathrm{z}$ dwóch form. Po pierwsze, było to zespolenie bezpośrednie, rozumiane jako służbowe podporządkowanie "pewnych spraw kierownictwu przedstawiciela rządu jako całości”. Po wtóre zaś, było to tak zwane zespolenie pośrednie, wyrażające się w „ustawowym zagwarantowaniu przedstawicielowi rządu wpływu na tok pracy innych urzędów, podległych centralnym władzom rządowym, bez poddawania jednak tych urzędów pod jego zwierzchnictwo służbowe"30.

\section{Stanisław Kasznica zauważa, że pośrednio wojewoda miał zapewniony}

daleko idący wpływ na działy administracji niezespolonej. Jest on na terenie województwa przedstawicielem rządu. Otóż w tym charakterze ma on prawo i obowiązek uzgadniania działalności całej administracji rządowej na tym obszarze w myśl zasadniczej linii politycznej rządu, jak również uzgadniania jej z potrzebami obrony państwa; wykonuje też ogólny nadzór policyjny nad funkcjonariuszami państwowymi. Z tego tytułu przysługuje wojewodzie szereg szczegółowych uprawnień: zwołuje on periodyczne zebrania naczelników władz regionalnych i przewodniczy na nich; — oddziałuje na treść wydawanych przez nich rozporządzeń; - winien być zapytywany o opinię o kandydatach zgłaszających się do służby państwowej, jako też przy obsadzaniu stanowisk samoistnych i kierowniczych etc. ${ }^{31}$

Reasumując tę część rozważań, należy podkreślić, że w pierwszym okresie kształtowania się modelu ustrojowego administracji pozycja prawna i polityczna wojewodów była wysoka i zaliczała wojewodę do kluczowych urzędów. W świetle częstych perturbacji na szczeblu rządowym władza wojewodów - mniej uzależnionych od układu sił politycznych i walki politycznej - była czynnikiem decydującym o ciągłości działania poszczególnych obszarów państwa ${ }^{32}$. Jak zaznacza Roman Hausner, w rękach wojewodów skoncentrowano bardzo duży zakres władzy państwowej ${ }^{33}$.

29 Jak zauważa S. Kasznica, postulat ten „został jednak spełniony tylko połowicznie. Do samej wojny pozostały wyłączone władze szkolne, skarbowe, ochrony pracy, jakkolwiek nie ma żadnych wystarczających racyj, nie pozwalających na wcielenie i tych działów, na równi z innymi, do województwa i starostwa na prawach wydziału czy referatu", idem, op. cit., s. 56. W podobnym tonie wypowiada się J. Starościak, op. cit., s. 21.

30 J. Starościak, op. cit., s. 21.

31 S. Kasznica, op. cit., s. 56.

32 Zob. A. Ajnenkiel, Administracja w Polsce. Zarys historyczny, Warszawa 1977, s. 57; K. Wojtczak, op. cit., s. 9.

${ }^{33}$ R. Hausner, op. cit., s. 381 (1). 
Niezbędne jest jednak podkreślenie, że przyjęte regulacje prawne nie zawsze spełniały oczekiwania piastunów stanowisk wojewodów, a w piśmiennictwie funkcjonuje pogląd, że faktyczna pozycja wojewodów jako reprezentantów rządu była zbyt mocno ograniczona i pozbawiona praktycznych narzędzi. Jak podkreśla Michał Gałędek, w analizowanym okresie wojewodowie „byli zupełnie pozbawieni jakichkolwiek kompetencji gwarantujących im skuteczną realizację funkcji przedstawiciela rządu”. Jego zdaniem odpowiednich regulacji nie zawierały zarówno ustawa z 1919 roku, jak i rozporządzenie wykonawcze ${ }^{34}$.

Poczyniony pogląd sformułowano na podstawie przekazu delegata rządu na ziemię wileńską, Walerego Romana, który podkreślał, że

konieczność realizacji w stopniu należytym zasady dekoncentracji oraz zespolenia agend pod jednym kierownictwem wymaga przede wszystkim, aby granice kompetencji wojewody były rozszerzone oraz ustosunkowanie się doń wszelkich innych agend i resortów działających i urzędujących na terenie województwa było przepisowo dostatecznie wyraźnie określone, wszechstronnie ujęte i zdefiniowane. Wojewoda występujący jako przedstawiciel centralnego rządu, sprawujący z jego ramienia władzę państwową - jest jedynie i wyłącznie odpowiedzialnym za bieg i kierunek polityki wewnętrznej w powierzonym sobie administracyjnym okręgu i za całokształt działania władzy państwowej pod względem politycznym i gospodarczym. W interesie jednolitości polityki i gwoli zapobieżeniu rozbieżności wojewoda winien mieć formalnie zapewnioną możliwość skutecznego oddziaływania na zamierzenia i kierunek ogólny czynności poszczególnych resortów jego władzy dotychczas niepodporządkowanych, występujących w danym okręgu administracyjnym i posiadających wpływ na bieg spraw na terenie okręgu. [...] Obecnie samorzutne i niezależne działania na własną rękę rozmaitych gałęzi administracji państwowej bez prawa wojewody wglądu i ogólnego kierownictwa stanowi niewątpliwie anomalię, sprzeczną z istotą zasad wyszczególnionych w konstytucji, zwłaszcza w art. 66 tejżz ${ }^{35}$.

W kontekście przywołanych problemów wielu urzędników i polityków oczekiwało reakcji ze strony ustawodawcy, aby poszerzyć zakres zespolenia lub zobowiązać władze poszczególnych jednostek do uzgadniania z wojewodą kluczowych zamierzeń i planów z jednoczesnym umożliwieniem nadzorowania sposobu ich wykonania. Jak podkreśla się $\mathrm{w}$ piśmiennictwie,

uwagi te uznano za w pełni zasadne szczególnie wobec działów o dużym znaczeniu politycznym i gospodarczym, jak szkolnictwo czy administracja odpowiedzialna za przeprowadzenie reformy rolnej. Nie pretendowano jednak do krępowania „fachowej działalności” poszczególnych urzędów, uznając, że w tym zakresie gwarancje pełnej samodzielności działania są jak najbardziej wskazane ${ }^{36}$.

Zmiany w sposobie wykonywania władztwa przez wojewodów wprowadzono stopniowo od 1923 roku, o czym będzie mowa w dalszej części pracy.

Na zakończenie tej części rozważań należy podkreślić, że moc ustawy tymczasowej z 1919 roku rozciągała się na wszystkie województwa II $\mathrm{RP}^{37}$ z wyjątkiem województw

34 M. Gałędek, Pozycja ustrojowa wojewodów i starostów jako przedstawicieli rządu w latach 1919-1928, „Studia Iuridica Toruniensia” 11, 2012, s. 14.

${ }^{35}$ LCVA, f. 51, ap. 15, b. 177, k. 8-9 - pismo Delegata Rządu na Ziemię Wileńską z 5 maja 1923 roku w przedmiocie uproszczenia administracji, cyt. za: M. Gałędek, op. cit., s. 14-15.

36 M. Gałędek, op. cit., s. 15.

37 Od 1919 roku obowiązywała w województwach centralnych, od 1921 roku w województwach galicyjskich i wschodnich, od 1922 roku na ziemi wileńskiej. 
byłego zaboru pruskiego oraz mającego odrębny status prawny i kompetencyjny województwa śląskiego ${ }^{38}$.

Warto jednak zauważyć, że

prawodawstwo stanowione w okresie formowania się państwowości polskiej było wybitnie niedoskonałe zarówno pod względem techniki legislacyjnej, jak i częściowo niedookreślonej i niespójnej warstwy merytorycznej. Tworzono je bowiem w pośpiechu, z samego założenia jedynie na krótki okres przejściowy, z myślą, iż nie tyle w perspektywie kilkuletniej, a co najwyżej kilkunastomiesięcznej zostanie ono zastąpione kompletną ustawą ${ }^{39}$.

\section{Wojewoda w systemie konstytucyjnych organów państwa polskiego w latach 1921-1928}

Kluczowym aktem ustrojowym ${ }^{40}$ kształtującym system państwowości polskiej, a w interesującym nas zakresie system administracji publicznej, była ustawa z dnia 17 marca 1921 roku - Konstytucja Rzeczypospolitej Polskiej ${ }^{41}$. Jak podkreśla się w doktrynie „Konstytucja z 1921 r., pragnąc stworzyć ogólny ustrój Państwa w oparciu o idealnie pojęte wytyczne demokracji, zamknęła w swych postanowieniach szereg wskazówek w odniesieniu do ustroju administracji publicznej"42.

W przedmiocie prowadzonych rozważań kluczowe są zapisy art. 3 i art. 65-66 Konstytucji ${ }^{43}$. W akapicie czwartym art. 3 wskazano, że „Rzeczpospolita Polska, opierając swój ustrój na zasadzie szerokiego samorządu terytorjalnego, przekaże przedstawicielstwom tego samorządu właściwy zakres ustawodawstwa, zwłaszcza z dziedziny administracji, kultury i gospodarstwa, który zostanie bliżej określony ustawami państwowemi”.

$\mathrm{W}$ innym przepisie wskazano, że

dla celów administracyjnych Państwo Polskie podzielone będzie w drodze ustawodawczej na województwa, powiaty i gminy miejskie i wiejskie, które będą jednocześnie jednostkami samorządu terytorialnego. Jednostki samorządowe mogą się łączyć w związki dla przeprowadzenia zadań, wchodzących w zakres samorządu. Związki takie mogą otrzymywać charakter publiczno-prawny tylko na podstawie osobnej ustawy.

W kontekście organizacji administracji państwowej zgodnie z założeniami ustawodawcy „przeprowadzana będzie zasada dekoncentracji. Organy administracji państwo-

38 Zob. R. Hausner, Organizacja władz administracyjnych, „Gazeta Administracji i Policji Państwowej” 1.07.1922, s. 398 (2) oraz S. Kasznica, Władze administracji ogólnej po dokonanej reorganizacji, „Ruch Prawniczy i Ekonomiczny" 1928, z. 2; Urząd wojewody w Poznaniu. Od X wieku do współczesności, red. S. Sierpowski, Poznań 1997.

39 M. Gałędek, Rozporzadzenie Prezydenta RP z 19 stycznia 1928 r. o organizacji i zakresie działania władz administracji ogólnej - przełom w budowie ustroju administracyjnego państwa polskiego doby międzywojennej, „Zeszyty Prawnicze UKSW” 2011, nr 11.3, s. 96. Zob. Archiwum Akt Nowych w Warszawie, Prezydium Rady Ministrów. Akta numeryczne, sygn. 10358/19, k. 9.

40 Zob. J. Kostrubiec, Ustrój administracji terytorialnej w świetle pierwszych projektów polskiej doktryny prawniczej u progu odrodzonej Rzeczypospolitej, „Studia Iuridica Lublinensia” 25, 2016, nr 3.

41 Ustawa z dnia 17 marca 1921 roku — Konstytucja Rzeczypospolitej Polskiej, Dz.U. z 1921 r. Nr 44, poz. 267.

42 J. Starościak, op. cit., s. 14.

43 W tekście Konstytucji nie użyto terminu „wojewoda”. 
wej w poszczególnych jednostkach terytorjalnych mają być przytem zespolone w jednym urzędzie pod jednym zwierzchnikiem" 44 .

Konstytucja ogólnie określiła organizację naczelnej władzy wykonawczej i nie tworzyła ram prawnych dotyczących administracji terenowej. Zapowiedziała jednak utworzenie jednostek samorządu terytorialnego. Wacław Kumaniecki, oceniając przyjęte w konstytucji marcowej rozwiązania, stwierdził:

trzeba przyznać, że jakkolwiek można jej [konstytucji - K.M.] postawić niejeden uzasadniony zarzut, to jednak właśnie ta jej część, która zawiera postanowienia o zasadach ustroju administracyjnego, należy może do względnie najlepszych. Mam na myśli nie tyle układ i redakcję prawniczą, ile raczej same zasady, tam wyrażone. Samorząd gminny, powiatowy i wojewódzki, przewidziane przez konstytucję, pozwolą lepiej i łatwiej spełniać szereg ważnych zadań administracji, stając się równocześnie szkołą życia publicznego, opartego nie tyle na polityce, ile na administrowaniu, a to i wyrabia zrozumienie, że administracja publiczna nie jest rzeczą łatwą i wytwarza poczucie odpowiedzialności u przedstawicieli ludności ${ }^{45}$.

Wracając do głównego nurtu rozważań i poruszonego wątku o praktycznych problemach w wykonywaniu przez wojewodów funkcji przedstawiciela rządu, warto przywołać działania podjęte przez decydentów politycznych po 1923 roku. Wówczas to podjęto między innymi poufne uchwały Rady Ministrów w sprawie reorganizacji administracji państwowej ${ }^{46}$. Treść merytoryczna przywołanych uchwał wynikała w dużej mierze z dorobku Komisji dla reformy administracji ${ }^{47}$. W wyniku prac komisji sformułowano ogólne zasady planowanej reformy. W interesującym nas zakresie zaproponowano następujące wytyczne:

- reprezentant administracji ogólnej (wojewoda, starosta) posiada wyłączne prawo reprezentowania Rządu przy uroczystych wystąpieniach, o ile Rząd nie wyśle specjalnego Delegata; reprezentant ten wywiera wpływ na zachowanie jednolitego kierunku we wszystkich władzach i urzędach administracji państwowej,

- wojewodowie powinni mieć wpływ na mianowanie urzędników na stanowiska samoistne i kierownicze we wszystkich działach administracji państwowej [...],

- wojewoda ma prawo ingerować w sprawy personalne resortów administracji innych działów z zastrzeżeniem decyzji resortowego ministra,

- wprowadza się instytucje perjodycznych zebrań naczelników władz II instancji pod przewodnictwem wojewody, celem uzgadniania działalności poszczególnych działów administracji w myśl zasadniczej linji polityki Rządu reprezentowanej przez wojewodów ${ }^{48}$.

Formalną emanacją poufnej instrukcji MSW w zakresie sprecyzowanych zasad ogólnych (z wyłączeniem opiniowania spraw personalnych przy powołaniu do służby pań-

44 Zob. R. Hausner, Dekoncentracja, „Gazeta Administracji i Policji Państwowej” 1.01.1929.

45 W. Kumaniecki, op. cit., s. 26 (2).

46 LCVA, f. 51, ap. 1, b. 49, k. 111-112v, cyt. za: M. Gałędek, Pozycja ustrojowa..., s. 15-16.

47 Zob. J. Przygodzki, Komisje dla usprawnienia administracji w Polsce w okresie międzywojennym, [w:] Dzieje biurokracji, t. 6, red. T. Bykowa, A. Górak, G. Smyk, Radzyń Podlaski 2016, s. 749-758; idem, Problematyka administracji publicznej na łamach „Gazety Administracji i Policji Państwowej” z 1923 roku, „Acta Universitatis Wratislaviensis. Prawo" 2013, nr 315/2, s. 113-126; idem, Przyczynek do problematyki dekoncentracji w pracach komisji dla usprawnienia administracji publicznej w II Rzeczypospolitej, „Studia z Dziejów Państwa i Prawa Polskiego" 2009, nr 12, s. 227-235.

48 Dookoła spraw administracyjnych. Organizacja władz administracyjnych, „Gazeta Administracji i Policji Państwowej” 26.05.1923, s. 353 (9). 
stwowej) było rozporządzenie Rady Ministrów z lutego 1924 roku ${ }^{49}$. Pozostałe kompetencje wymagały szerszych działań legislacyjnych i koordynacyjnych i były w dużej mierze uzależnione od porozumienia politycznego ${ }^{50}$. Odpowiedzialne za sprawy organizacji aparatu administracyjnego państwa MSW wydawały wiele szczegółowych dyrektyw proceduralnych, zawartych w kolejnych instrukcjach i okólnikach. Przykładem może być okólnik z czerwca 1924 roku w zakresie precyzowania środków oddziaływania wojewodów w ramach sprawowanej funkcji przedstawiciela rządu. Podkreślono w nim jednoznacznie, że w interesie skoordynowania działalności całej administracji państwowej na obszarze poszczególnych województw, a co za tym idzie wzmocnienia powagi władzy państwowej w ogóle zarówno, jak i zapewnienia wojewodom odpowiedniego wglądu w ogół działalności administracji państwowej na obszarze województwa, ze szczególnym uwzględnieniem spraw personalnych ${ }^{51}$

należy wzmocnić ich uprawnienia w zakresie prowadzenia jednolitej i spójnej polityki rządowej.

Wzmocnienie funkcji koordynacyjnej wojewody było z całą pewnością kluczowym zamierzeniem charakteryzowanej zmiany. Wprowadzenie formalnych mechanizmów skłaniających przedstawicieli poszczególnych władz do ustalania w ramach spotkań wspólnych kierunków działania, omawiania bieżących problemów administracji oraz rozwiązywania potencjalnych sporów było z pewnością pożądanym kierunkiem postępowania. Jak podkreślano, miała to być instytucja, która by „ułatwiała koordynowanie działalności wszystkich władz i urzędów państwowych, stwarzała sposobność łatwego i bezpośredniego wzajemnego porozumienia i rozpatrywania wątpliwości kompetencyjnych i usuwania szkodliwej dla państwa rozbieżności zarządzeń" 52 . Co ważne, wojewoda w ramach zebrań periodycznych był tylko „primus inter pares”, co „przy pokutującym u nas ciągle jeszcze dużym patrjotyzmie resortowym" było pozytywną stroną tej instytucji ${ }^{53}$. Roman Hausner, analizując wpływ zebrań, dostrzegł wiele korzyści w realizowaniu funkcji i zadań przez wojewodów oraz pozytywny wpływ na sprawność i jakość procesów decyzyjnych ${ }^{54}$.

Syntetyzując poczynione rozważania, należy podzielić pogląd, że „W okresie przed unifikacją administracji prawidłowe i pełne stosowanie uprawnień służących wojewodom i starostom do realizacji funkcji przedstawiciela rządu napotykało na różnorakie problemy", co wydłużało proces ponad miarę. Warto również zwrócić uwage na wysoką determinację czynników politycznych do przeprowadzenia reformy pomimo świadomości istnienia ryzyk i braku spójnej i pełnej koncepcji. W działaniach decydentów

49 Rozporządzenie Rady Ministrów z dnia 11 lutego 1924 roku w przedmiocie organizacji władz administracyjnych II instancji, Dz.U. z 1924 r. Nr 21, poz. 225.

50 Zob. szerzej M. Gałędek, Pozycja ustrojowa..., s. 18-45.

51 LVCA, f. 51, ap. 1, b. 49, k. 114 - okólnik ministra spraw wewnętrznych nr 73 z 26 czerwca 1924 r. w sprawie organizacji władz administracyjnych II instancji, cyt. za: M. Gałędek, Pozycja ustrojowa..., s. 19.

52 LCVA, f. 51, ap. 1, b. 49, k. 31 - pismo ministra spraw wewnętrznych z 24 lutego 1925 r. w sprawie regulaminu zebrań periodycznych, cyt. za: ibidem, s. 20.

53 R. Hausner, Zespolenie w świetle wojewódzkich zebrań perjodycznych, „Gazeta Administracji i Policji Państwowej” 1.01.1930, s. 10 (10). W artykule tym bardzo szczegółowo scharakteryzowano zakres, tryb organizowania i procedowania w ramach zebrań periodycznych po reformie z 1928 roku.

54 R. Hausner, Zebrania naczelników władz w województwach i powiatach, „Gazeta Administracji i Policji Państwowej” 2.10.1926, s. 622-623 (9-10). 
pojawiały się zabiegi noszące znamiona chaosu, jednak w rządzie zwyciężyła opcja reprezentowana przez Ministra Spraw Wewnętrznych jako głównego orędownika zmian ${ }^{55}$.

Warto zwrócić uwagę, że wielu uczestników procesów decyzyjnych związanych z reformowaniem i poszerzaniem kompetencji wojewodów o nowe uprawnienia celowo opóźniało prace z tym związane. Wynikało to w dużej mierze z niechęci do utraty władztwa „resortowego" nad poszczególnymi procesami realizowanymi w terenie przez administrację niezespoloną. Przejawem oporu wobec zmian były liczne interpelacje, w których

interpretowano zarówno przepisy wprowadzające zebrania wojewódzkie, jak i przede wszystkim zapewniające wojewodom wpływ na sprawy personalne całej administracji rządowej jako dążenie do poddania działów niezespolonych, a szczególnie szkolnictwa pod supremację wojewody i wprowadzenia tym samym „polityki do szkół"56.

Okres między 1921 a 1928 rokiem uznawany jest w literaturze za czas wyraźnej unifikacji oraz zespalania poszczególnych działów administracji w terenie. Zdaniem Jerzego Służewskiego „w tym okresie zaznaczyło się także wzmocnienie wpływów wojewodów i starostów, jako organów administracji ogólnej, na urzędy administracji nie zespolonej, głównie w formie funkcji koordynacyjnej” ${ }^{\text {"2 }}$. Należy zgodzić się z tym poglądem, gdyż władze rządowe na każdym szczeblu wkładały wiele wysiłków, aby centralizacja i unifikacja odbudowywanego państwa zakończyła się sukcesem. Warto jednak pamiętać, że konsolidacja nie była wdrażana bez oporu polityków czy też problemów natury organizacyjnej i prawnej. To w konsekwencji przekładało się na zdolność państwa do realizowania kluczowych zadań w tak trudnym okresie.

Nie ulega wątpliwości, że przewrót majowy istotnie wpłynął na kształt sceny politycznej, system polityczny, a tym samym system administracji publicznej. Szczegółowe dane na temat zmian personalnych $w$ aparacie urzędniczym i quasi-politycznym po przewrocie majowym były przedmiotem analiz naukowych i nie będą przywoływane $\mathrm{w}$ tym miejscu ${ }^{58}$. Autor ograniczy się jedynie do stwierdzenia, że przewrót majowy dokonany przez piłsudczyków miał istotny wpływ na sprawy personalne poszczególnych typów administracji.

W nurcie zasadniczych rozważań należy zauważyć, że po 1926 roku tendencje zmierzające do koncentracji aparatu administracyjnego oraz wzmacniania centralizmu biurokratycznego przybrały na sile i znaczeniu ${ }^{59}$. Prawnym wyrazem zasygnalizowanych tendencji było rozporządzenie Prezydenta z 19 stycznia 1928 roku o organizacji i zakresie działania władz administracji ogólnej ${ }^{60}$. Akt ten obowiązywał na terytorium całej Rzeczypospolitej z wyjątkiem województwa śląskiego, gdzie nadal obowiązywały rozstrzygnięcia statutu organicznego, ustaw Sejmu Śląskiego i stosownych aktów wykonaw-

55 M. Gałędek, Pozycja ustrojowa..., s. 41-42.

56 Ibidem.

57 J. Służewski, Wojewoda w systemie administracji państwowej, Warszawa 1981, s. 13.

58 Kto był kim w Drugiej Rzeczypospolitej, red. J.M. Majchrowski, Warszawa 1994; J. Majchrowski, op. cit., s. 75-93, W. Kozyra, op. cit., s. 59-87; Urzad wojewody w Poznaniu..., s. 129-143.

59 Por. J. Służewski, Wojewoda w systemie..., s. 25.

60 Rozporządzenie Prezydenta Rzeczypospolitej z dnia 19 stycznia 1928 roku o organizacji i zakresie działania władz administracji ogólnej, Dz.U. z 1928 r. Nr 11, poz. 86. 
czych $^{61}$. Należy podzielić pogląd, że analizowany akt prawny sfinalizował w dużej mierze unifikację administracji na terytorium odradzającego się państwa polskiego. Do styczniowego rozporządzenia wydano ponad czterysta aktów wykonawczych, które w systemowy sposób kształtowały ustrój wojewódzkiej administracji ogólnej.

W opinii Andrzeja Ajnenkiela rozporządzenie

podniosło i tak już wysoki prestiż wojewody. Było to stanowisko na wskroś polityczne, którego zakres funkcji sprowadzał się przede wszystkim do nadzoru nad stosunkami społecznymi, politycznymi na podległym mu obszarze, do oddziaływania na posunięcia opozycji lub jej hamowania. Wojewoda koordynował też działalność represyjną, w szczególności przeciwko ruchowi rewolucyjnemu. Tak więc w urzędzie tym nastąpiło znacznie wyraźniej zespolenie funkcji klasowych, funkcji represji i wreszcie funkcji politycznych zmierzających w działaniu do utrwalenia istniejącej struktury społecznej i władzy rządzącego obozu ${ }^{62}$.

Celem rozporządzenia była chęć wprowadzenia jednolitej organizacji władz administracji ogólnej, opartej na zasadach płynących z konstytucji marcowej ${ }^{63}$. Zgodnie z art. 2 rozporządzenia władzami administracji ogólnej byli „wojewodowie, komisarz rządu, starostowie powiatowi i starostowie grodzcy oraz organa komunalne, które spełniają zadania administracji ogólnej w zakresie, ustalonym przez rozporządzenie niniejsze oraz inne przepisy prawne" 64 .

$\mathrm{Z}$ uwagi na przyjęte kryterium temporalne artykułu styczniowe rozporządzenie nie będzie poddawane szczegółowej analizie.

\section{Czynniki wpływające na jakość decydowania publicznego wojewody w pierwszym okresie funkcjonowania II Rzeczypospolitej}

Kluczowym czynnikiem negatywnie wpływającym na jakość decydowania wojewodów było nadmierne rozproszenie struktur administracyjnych, a także nieodpowiednia jakość kadr urzędniczych. Rozproszenie struktur i brak efektywnych mechanizmów komunikacji z całą pewnością wpływały na szybkość i jakość procesów decyzyjnych. Bardzo często decyzje podejmowano bez pełnego oglądu sprawy. Warto również zauważyć, że brak merytorycznej kadry przygotowanej do realizacji zadań w warunkach niepewności oraz brak spójnej wizji decydentów politycznych wpływały na jakość decydowania.

Po drugie, negatywnie na jakość decydowania wpływała różnorodność unifikowanych systemów administracyjnych państw zaborczych, a tym samym różny stopień rozwoju aparatu administracyjnego. W tym kontekście szczególnie istotne było zaplecze organizacyjne i merytoryczne wspierające procesy decyzyjne realizowane przez wojewodów.

Po trzecie, czynnikiem negatywnie wpływającym na procesy decyzyjne analizowane z perspektywy makropaństwowej było nadmierne rozproszenie sceny politycznej, a tym

61 A. Tarnowska, Niedostatki unifikacji administracji ogólnej: doktryna i praktycy o koniecznych uzupełnieniach rozporządzenia Prezydenta RP z dnia 19 stycznia 1928 r., „Studia Iuridica Toruniensia” 17, 2015 , s. 255.

62 A. Ajnenkiel, op. cit., s. 89.

63 Zob. R. Hausner, Organizacja i zakres działania władz administracji ogólnej, „Gazeta Administracji i Policji Państwowej” luty 1928, s. 91 (1).

64 Art. 2 rozporządzenia Prezydenta Rzeczypospolitej z dnia 19 stycznia 1928 roku o organizacji i zakresie działania władz administracji ogólnej, Dz.U. z 1928 r. Nr 11, poz. 86. 
samym wikłanie wojewodów w spory polityczne i partyjne. Uzależnianie wojewodów od układów partyjnych wpływało na proces decydowania szczególnie w kontekście wyboru możliwych wariantów decyzyjnych. Dużo częściej zwyciężał pogląd partyjny na dane zagadnienie wbrew założeniom, że to interes państwa jako całości jest kluczowy.

Po czwarte, istotnym elementem, który wpływał na procesy decydowania, był brak mechanizmów pozwalających na przekładanie celów strategicznych rządu na cele operacyjne administracji terytorialnej. Wątek ten był wielokrotnie podnoszony przez środowiska eksperckie i naukowe, jednak został wdrożony dopiero przed wybuchem drugiej wojny światowej. Wynikało to jednak w dużej mierze $\mathrm{z}$ chęci wdrażania skutecznych mechanizmów kontroli przez poszczególnych ministrów, a nie systemowe podejście do zarządzania sprawami publicznymi.

Ważnym czynnikiem wpływającym na jakość procesów decyzyjnych było również zakorzenione w polskiej tradycji urzędniczej dążenie do „resortowego” postrzegania systemu administracji i wynikającej z tego chęci budowania własnego zaplecza organizacyjno-administracyjnego i decyzyjnego. Wielu decydentów $\mathrm{w}$ fazie deklaratywnej popierało działania nakierowane na modernizację (na przykład zespolenie administracji w ramach urzędu wojewody), przy czym w fazie realizacji (na przykład oceny konkretnego projektu) wskazywało na niemożność zespolenia kierowanej gałęzi systemu administracyjnego.

Czynnikiem pozytywnie wpływającym na jakość decydowania była z pewnością działalność różnego rodzaju ciał doradczych i eksperckich. W tym kontekście należy zwrócić uwagę na działalność trzech komisji wspierających centrum rządowe w kształtowaniu modelu ustrojowego administracji oraz dostarczaniu propozycji rozwiązań kluczowych problemów państwa polskiego.

Pozytywnie na jakość decydowania wpływała również sprawna budowa aparatu urzędniczego. O ile bowiem w pierwszym etapie kształtowania się modelu ustrojowego administracji ogólnej był to czynnik negatywnie wpływający na decydowanie, o tyle w latach trzydziestych XX wieku kadry pozytywnie wpływały na jakość decyzji. Pozytywnie w tym ujęciu rysuje się także zdolność decydentów i ekspertów do wykorzystywania doświadczeń państw zaborczych.

Analizując rolę kadr urzędniczych, należy mieć jednak na uwadze, że po przewrocie majowym nastąpiły „rugi w administracji”, czyli fala politycznych czystek i obniżenie kryteriów merytorycznych ${ }^{65}$. W piśmiennictwie podkreśla się, że „o ile do przewrotu majowego główną rolę w polityce kadrowej odgrywały kwalifikacje zawodowe, o tyle po 1926 roku coraz większe znaczenie zyskiwała zbieżność poglądów politycznych urzędnika z linią obozu rządzącego. Nastąpił proces głębokiej polityzacji służby cywilnej”66.

Nie ulega wątpliwości, że na procesy decydowania publicznego pozytywnie wpływał wysoki poziom zaangażowania społeczeństwa oraz wytrwałość w dążeniu do budowania instytucji państwa polskiego.

65 Ł. Świetlikowski, Mobilność urzędnicza w polskiej służbie cywilnej jako problem polityki administracyj$n e j$, praca doktorska obroniona na Wydziale Dziennikarstwa i Nauk Politycznych Uniwersytetu Warszawskiego, Warszawa 2015, s. 83.

66 J. Kornaś, Administracja publiczna w Polsce, [w:] Administracja publiczna, red. J. Hausner, Warszawa 2003, s. 128. 
Przystępując do ogólnej syntezy, warto podkreślić, że z jednej strony tempo prac unifikujących i reformujących system administracji publicznej odradzającego się państwa polskiego było imponujące, z drugiej zaś można mieć poczucie, że zwłaszcza w okresie od 1921 do 1928 roku „zmitrężono przynajmniej kilka lat”67. Teza o „zmitrężonym” okresie, sformułowana przez Michała Gałędka, poparta została między innymi analizą klimatu politycznego wokół zagadnień związanych z reformowaniem administracji publicznej. Klimat ten dobrze oddają słowa członków „Komisji Trzech” ${ }^{68}$, powołanej w 1926 roku do opracowania koncepcji reformy administracji państwowej, którzy stwierdzili, że

podjęliśmy pracę naszą jako znawcy przedmiotu, nie licząc się ze względami politecznemi, ani też z naturalnym oporem, który z istniejącej organizacji administracyjnej wydobywa się zawsze przeciw dalej sięgającym zmianom. Prowadziliśmy pracę naszą wśród zgodnego chóru głosów, które w publicystyce przemawiały za najdalej idącą reformą administracji. Każdy niemal jednak z tych głosów wykluczał od tej reformy pewną dziedzinę, którą się szczególniej interesował i którą chciał mieć nietkniętą, a gdyby wszystkie te wyjątki zestawić, pokazałoby się, że, mimo powszechnego żądania reformy, prawie żadna reforma praktycznie nie jest możliwa. Nie naszą rzeczą było więc przed tym oporem się cofać i przesądzać tem samem, co z wniosków naszych przyjmie rząd, co przyjmie Sejm i Senat ${ }^{69}$.

Przywołane słowa doskonale obrazują nastroje związane z panującym wówczas klimatem wśród decydentów politycznych. Nastawienie do zmiany było pozytywne, pod warunkiem, że dotyczyło obszaru innego decydenta. Zjawisko to jest znane również dzisiaj, gdyż bardzo często działania modernizujące system świadczenia usług publicznych i organizacji struktur administracyjnych blokowane są na podstawie identycznych argumentów. To z kolei prowadzi do powstawania zjawiska „zamkniętej twierdzy”, pogłębiającego niemoc w zakresie odważnych reform i odcinanie się przez administrację od realnych problemów obywateli i innych interesariuszy.

\section{Podsumowanie}

Mimo przedstawionych wątpliwości i uwarunkowań należy podzielić pogląd Andrzeja Ajnenkiela, który analizując pozycję wojewody w początkowym okresie unifikacji niepodległej Polski, stwierdził, że

pozycja wojewody była wysoka. W krótkim czasie funkcja ta stała się jedną z kluczowych w aparacie administracyjnym. Niejednokrotnie władza wojewody - mniej uzależnionego od układu sił politycznych w Sejmie aniżeli minister - była czynnikiem decydującym o ciągłości działania administracji w terenie. Urząd wojewody stawał się niejednokrotnie szczeblem do dalszej kariery administracyjnej czy politycznej ${ }^{70}$.

W podobnym tonie wypowiada się Waldemar Kozyra, który twierdzi, że „władze administracji ogólnej, tj. wojewodowie i starostowie wraz ze swymi urzędniczymi sztabami, stanowiły decydujący trzon administracji terenowej i nadawały ton całej administra-

${ }^{67}$ M. Gałędek, Rozporządzenie Prezydenta RP..., s. 96.

68 W skład komisji wchodzili: M. Bobrzyński, S. Kasznica, S. Smólski.

69 M. Bobrzyński, S. Kasznica, S. Smólski, Zagadnienie reformy administracji. Sprawozdanie Komisji powołanej przez p. Prezesa Rady Ministrów do opracowania projektu reorganizacji administracji państwowej, „Gazeta Administracji i Policji Państwowej” 6.03.1926, s. 156 (4).

70 A. Ajnenkiel, op. cit., s. 57. 
cji państwowej tego okresu"71. Inny autor, Zbigniew Dworecki, analizujący pozycję i rolę wojewody poznańskiego podkreśla, że

stanowisko wojewody [w II Rzeczypospolitej - K.M.] było na wskroś polityczne. Udzielał on dyrektyw ze stanowiska politycznego i interesu publicznego. Czynił to bądź w myśl zarządzeń władz centralnych, bądź z własnej inicjatywy. Koordynując działalność całej administracji państwowej zasadniczej linii działania rządu, a także sprawując ogólny nadzór nad funkcjonariuszami państwowymi ze stanowiska wymogów bezpieczeństwa i spokoju publicznego oraz interesów regionu - nadzorował tym samym stosunki społeczne i polityczne na podległym mu obszarze i wywierał istotny wpływ na ich kształtowanie ${ }^{72}$.

Warto jednak podkreślić, że polityczność wojewodów w systemie organów państwa - niezależnie od ustroju czy okresu - jest czymś oczywistym. Wojewoda, będąc istotnym elementem systemu politycznego i administracyjnego, z całą pewnością był organem politycznym. Należy założyć, że autorowi przywołanej wypowiedzi chodziło o upolitycznienie rozumiane jako upartyjnienie urzędu wojewody i sprowadzenie go do realizacji partykularnych interesów poszczególnych ugrupowań politycznych ${ }^{73}$.

W świetle przywołanych w niniejszym artykule argumentów należy stwierdzić, że sformułowana na wstępie hipoteza została zweryfikowana pozytywnie. Wojewoda w pierwszym okresie kształtowania się państwowości polskiej stanowił kluczowy element procesu kształtowania się administracji terenowej. Korzystając z uprawnień koordynacyjnych i nadzorczych, pozytywnie wpływał na tempo budowania struktur administracji terenowej oraz sposób wykonywania zadań.

\section{Bibliografia}

Ajnenkiel A., Administracja w Polsce. Zarys historyczny, Książka i Wiedza, Warszawa 1977.

Bobrzyński M., Kasznica S., Smólski S., Zagadnienie reformy administracji. Sprawozdanie Komisji powołanej przez p. Prezesa Rady Ministrów do opracowania projektu reorganizacji administracji państwowej, „Gazeta Administracji i Policji Państwowej" 6.03.1926.

Decydowanie publiczne. Polska na tle innych państw członkowskich Unii Europejskiej, red. G. Rydlewski, Dom Wydawniczy Elipsa, Warszawa 2011.

Dookoła spraw administracyjnych. Organizacja władz administracyjnych, „Gazeta Administracji i Policji Państwowej" 26.05.1923.

Dubiel K., Rozporządzenia porządkowe, „Gazeta Administracji i Policji Państwowej” 1.02.1929.

Gałędek M., Pozycja ustrojowa wojewodów i starostów jako przedstawicieli rządu w latach 1919-1928, „Studia Iuridica Toruniensia" 11, 2012.

Gałędek M., Rozporzadzenie Prezydenta RP z 19 stycznia 1928 r. o organizacji i zakresie działania władz administracji ogólnej - przełom w budowie ustroju administracyjnego państwa polskiego doby międzywojennej, „Zeszyty Prawnicze UKSW” 2011, nr 11.3.

Hausner R., Dekoncentracja, „Gazeta Administracji i Policji Państwowej” 1.01.1929.

71 W. Kozyra, Polityka administracyjna ministrów spraw wewnętrznych Rzeczypospolitej Polskiej w latach 1918-1939, Lublin 2009, s. 90.

72 Z. Dworecki, $W$ odrodzonej Polsce, [w:] Urzad wojewody w Poznaniu..., s. 70.

73 Refleksje na temat zakresu pojęć „polityzacja” (upolitycznienie) i „upartyjnienie” były przedmiotem rozważań autora i wyrażone wówczas poglądy nadal zachowują aktualność. Zob. K. Mroczka, Wpływ polityki zarzadzania zasobami ludzkimi w służbie cywilnej na funkcjonowanie państwa, Warszawa 2015, s. $50 \mathrm{n}$. 
Hausner R., Organizacja władz administracyjnych, „Gazeta Administracji i Policji Państwowej” 24.06.1922. Hausner R., Organizacja władz administracyjnych, „Gazeta Administracji i Policji Państwowej” 1.07.1922.

Hausner R., Rozporządzenie o stanowisku wojewodów i starostów jako przedstawicieli Rządu, „Gazeta Administracji i Policji Państwowej" 15.09.1931.

Hausner R., Wykonanie rozporzadzenia Prezydenta Rzeczypospolitej o organizacji i zakresie działania władz administracji ogólnej, „Gazeta Administracji i Policji Państwowej” wrzesień 1928.

Hausner R., Zebrania naczelników władz w województwach i powiatach, „Gazeta Administracji i Policji Państwowej" 2.10.1926.

Hausner R., Zespolenie w świetle wojewódzkich zebrań perjodycznych, „Gazeta Administracji i Policji Państwowej" 1.01.1930.

Izdebski H., Kulesza M., Administracja publiczna. Zagadnienia ogólne, Liber, Warszawa 2000.

Kasznica S., Polskie prawo administracyjne. Pojęcia i instytucje zasadnicze, Księgarnia Akademicka, Poznań 1947.

Kasznica S., Władze administracji ogólnej po dokonanej reorganizacji, „Ruch Prawniczy i Ekonomiczny” 1928, z. 2.

Knopek J, Europejskie systemy polityczne, Difin, Warszawa 2016.

Kornaś J., Administracja publiczna w Polsce, [w:] Administracja publiczna, red. J. Hausner, Warszawa 2003.

Kostrubiec J., Ustrój administracji terytorialnej w świetle pierwszych projektów polskiej doktryny prawniczej u progu odrodzonej Rzeczypospolitej, „Studia Iuridica Lublinensia” 25, 2016, nr 3.

Kozyra W., Polityka administracyjna ministrów spraw wewnętrznych Rzeczypospolitej Polskiej w latach 19181939, Wydawnictwo UMCS, Lublin 2009.

Kozyra W., Urząd wojewódzki w Lublinie w latach 1919-1939, Wydawnictwo UMCS, Lublin 1999.

Kto był kim w Drugiej Rzeczypospolitej, red. J.M. Majchrowski, Polska Oficyna Wydawnicza „BGW”, Warszawa 1994.

Kumaniecki W., Wzmocnienie państwa a administracja, „Gazeta Administracji i Policji Państwowej” 12.01.1924.

LCVA, f. 51, ap. 1, b. 49, k. 109 - poufne pismo ministra spraw wewnętrznych z 26 czerwca 1924 r. w sprawie władz administracyjnych II instancji.

LCVA, f. 51, ap. 1, b. 49, k. 31 - pismo ministra spraw wewnętrznych z 24 lutego 1925 r., w sprawie regulaminu zebrań periodycznych.

LCVA, f. 51, ap. 15, b. 177, k. 8-9 - pismo Delegata Rządu na Ziemię Wileńską z 5 maja 1923 r. w przedmiocie uproszczenia administracji.

LVCA, f. 51, ap. 1, b. 49, k. 114 - okólnik ministra spraw wewnętrznych nr 73 z 26 czerwca 1924 r. w sprawie organizacji władz administracyjnych II instancji.

Majchrowski J., Ewolucja funkcji wojewody jako przedstawiciela Rzadu, Wydawnictwo Uniwersytetu Warszawskiego, Warszawa 2011.

Mroczka K., Wplyw polityki zarzadzania zasobami ludzkimi w stużbie cywilnej na funkcjonowanie państwa, Dom Wydawniczy Elipsa, Warszawa 2015.

Organizacja władz administracji ogólnej. Wywiad dziennika „Epoka” z wiceministrem dr. Jaroszyńskim, „Gazeta Administracji i Policji Państwowej” luty 1928.

Przygodzki J., Komisje dla usprawnienia administracji w Polsce w okresie międzywojennym, [w:] Dzieje biurokracji, t. 6, red. T. Bykowa, A. Górak, G. Smyk, Radzyń Podlaski 2016.

Przygodzki J., Problematyka administracji publicznej na łamach „Gazety Administracji i Policji Państwowej” $z 1923$ roku, „Acta Universitatis Wratislaviensis. Prawo” 2013, nr 315/2.

Przygodzki J., Przyczynek do problematyki dekoncentracji w pracach komisji dla usprawnienia administracji publicznej w II Rzeczypospolitej, „Studia z Dziejów Państwa i Prawa Polskiego” 2009, nr 12.

Rozporządzenie Prezydenta Rzeczypospolitej z dnia 19 stycznia 1928 roku o organizacji i zakresie działania władz administracji ogólnej, Dz.U. z 1928 roku Nr 11, poz. 86.

Rozporządzenie Rady Ministrów z dnia 11 lutego 1924 roku w przedmiocie organizacji władz administracyjnych II instancji, Dz.U. z 1924 r. Nr 21, poz. 225. 
Rozporządzenie Rady Ministrów z dnia 19 marca 1924 roku w przedmiocie utworzenia Rad Wojewódzkich w województwach: nowogródzkiem, poleskiem, wołyńskiem i w okręgu administracyjnym wileńskim, Dz.U. z 1924 r. Nr 34, poz. 352.

Rozporządzenie Rady Ministrów z dnia 21 marca 1921 roku o organizacji władz administracyjnych drugiej instancji na ziemiach, przyłączonych do obszaru Rzeczypospolitej na podstawie umowy o preliminaryjnym pokoju i rozejmie, podpisanej w Rydze dnia 12 października 1920 roku, Dz.U. z 1921 r. Nr 39, poz. 235.

Rozporządzenie wykonawcze do Ustawy Tymczasowej z dnia 2 sierpnia 1919 roku o organizacji Władz Administracyjnych II instancji, Dz.U. z 1920 r. Nr 19, poz. 96.

Rozporządzenie wykonawcze Rady Ministrów do ustawy tymczasowej z dnia 2 sierpnia 1919 roku o organizacji władz administracyjnych drugiej instancji, Dz.U. z 1919 r. Nr 90, poz. 490.

Służewski J., Wojewoda w systemie administracji państwowej, Wydawnictwo Prawnicze, Warszawa 1981.

Starościak J., Administracyjny ustrój Polski, Czytelnik, Warszawa 1947.

Tarnowska A., Niedostatki unifikacji administracji ogólnej: doktryna i praktycy o koniecznych uzupetnieniach rozporzadzenia Prezydenta RP $z$ dnia 19 stycznia 1928 r., „Studia Iuridica Toruniensia” 17, 2015.

Urząd wojewody w Poznaniu. OdX wieku do współczesności, red. S. Sierpowski, Wydawnictwo WBP, Poznań 1997.

Ustawa tymczasowa z dnia 2 sierpnia 1919 roku o organizacji władz administracyjnych II instancji, Dz.Pr.P.P. z 1919 r. Nr 65, poz. 395.

Ustawa z dnia 17 marca 1921 roku — Konstytucja Rzeczypospolitej Polskiej, Dz.U. z 1921 r. Nr 44, poz. 267.

Wojtczak K., Pozycja prawna wojewody, Instytut Organizacji Zarządzania i Doskonalenia Kadr, Warszawa 1986.

\section{The position and the role of the province governor in the system of public deciding in the period of the Second Polish Republic (in the years 1919-1928) in the context of creating structures of the territorial administration}

Keywords: province governor, public deciding, government administration, territorial administration, the Second Polish Republic

\section{Summary}

The aim of the article is to analyze the position and role of the voivode in the public decision-making process of the Second Polish Republic, in the context of creating administrative structures. This is an important issue due to the spectacular and impressive rate of development of the political model of the territorial administration in Poland after the First World War. 